\title{
Prediction of Wind Flow Change around the Development Area Caused by Land Deformation and Tree Felling
}

by Tomoko WATANABE ${ }^{\mathrm{a}}$, Naohiro OTSUKA ${ }^{\mathrm{a}}$ and Mitsugu SAITO ${ }^{\mathrm{a}}$

a. Faculty of Engineering, Iwate University, Ueda, Morioka 020-8551, Japan

\begin{abstract}
Land deformation and tree felling caused by the development actions influences on the wind shift around the development areas. We defined the topographical features that affected the wind flow as a topographical factor. We also defined the decrease in the wind velocity by trees as a tree factor. The AMeDAS weather stations were classified into 4 topographical feature forms by these topographical factors' conditions. These were coast, flatland, flatland mixed with mountain and mountain valley. From the viewpoint of macroclimate, Tohoku district was divided into the Japan Sea side and the Pacific Ocean side.

Statistical study was conducted to investigate the relation between influences the factors and the wind flow. Multiple regression analysis using the factors could reach the relative equations for the frequency of the wind direction and the mean of the wind velocity for the flatland mixed with mountain in summer and winter.

Using the relative equations as the prediction formulas, it was examined the prediction of the wind flow change at the development area which had land deformation. As a result, it was predicted that the wind flow around the development area would change caused by development.
\end{abstract}

KEY WORDS : Development Area, Wind Direction, Wind Velocity, Topographical Factor, Tree Factor

\section{1.は じめに}

露天採掘などの森林伐採や地形改変を伴う開発は, 生態系や自 然景観の破壊，さらに微気象の変化など周辺の環境に様々な影響 を与える ${ }^{112)}$ 。ここで微気象とは, 局部的地形差によって生じる数 $\mathrm{km}$ 範囲の気候のことである。特に微気象のなかでも重要な要素で ある風体系の変化は, 他の微気象要素を左右するだけではなく, いままで風が吹かなかった地域に風が吹き込むようになるなどの 風害を発生させ問題となる場合がある ${ }^{3)}$ 。したがって，風と地形 との関係を定量化し, 地形改変を伴う開発が周辺地域の風体系に どのような影響を与えるかを予測することは，環境アセスメント の観点からも重要である。

風の流れに関寸る研究としては，大気污染に関わる大気の流れ に関する研究 ${ }^{4)}$, 林学分野における防風林に関する研究 5)6) など これまで多くの研究が行われている。しかし, 森林の伐採や地形 改変を伴う開発地域周辺の風体系変化に関する研究は国内外を問 わずほとんど行われていない現状にある。

風が地形によって変化する場合, 様々な地表の状態や, 構造物 や植生による地表面粗度などが影響を及ぼしていると考えられ る。そこで本研究では, 風の流れに影響を与える地形の状態を表 す因子として，地形の開け具合，高低差などを取り上げ，地形因 子として定義した。また, わが国では通常, 山地は樹木で覆われ

\footnotetext{
* 2001 年 9 月 20 日受付 2002 年 5 月 24 日受理 資源 ・素材学会平成 12 年度 秋季大会において一部発表

1. 学生会員 岩手大学大学院生 工学研究科生産開発工学専攻 博士後期課程

2. 普通会員 工博 岩手大学教授 工学部建設環境工学科

3. 普通会員 岩手大学助手 工学部建設環境工学科

[著者連絡先] FAX 019-621-6451 (岩手大・工・建設環境)

キーワード : 開発地域，風向，風速，地形因子，樹木因子
}

ている場合がほとんどであり, 地形改変に伴って樹木の伐採も行 われること, 樹木には大きな減風効果があることなどから, 地形 以外で特に風速に影響を及ぼす因子として樹木を取り上げた。そ して, 露天採掘などの地形改変を伴う開発地域周辺の風の流れの 変化を予測するために, 東北 6 県のアメダス気象観測点を対象と して, 観測点における風向, 風速と観測点周辺の地形因子および 樹木因子との関係について, 重回帰分析を用いて統計的検討を行 い関係式を導いた。

次に，導かれた関係式を予測式として用いて，地形改変を伴う 開発計画を事例として, 開発に伴う周辺地域の風向および風速の 変化について予測を行った。

\section{2. 風の流れの循環規模と地域性}

大気境界層内で起こる局地風や海風，陸風などに見られる大気 の状態は, 地表面状態の影響を受けて局地循環として生じるので, 上空の自由大気における風の循環と区別する必要がある7）。すな わち, 日常われわれが生活を営む大気境界層における風の流れは, 上空の自由大気の流れが地形や地表面の影響を受けて複雑に変化 したものであるといえる。したがって, 地形改変が周辺地域の風 体系にどのような影響を及ぼすかを解析するに当たっては, 地表 付近で観測された気象データを用いる必要がある。

そこで本研究では，地表付近において気象観測が行われている アメダス気象観測点を対象とすることとした。アメダス気象観測 点の風向風速計の設置高さは通常 $6.5 \mathrm{~m}$ であり, 地表風を対象と している。なお, 設置高さの異なる観測点については, 高さ 6.5 $\mathrm{m}$ における観測值になるように補正して解析に用いた。これらの 観測点は位置が既知であり周辺の地形情報を得るのが容易であ 
ること，継続した観測が行われていること，さらにデータの入手 が容易であることなどから，研究対象として最適であると考えら れる。

また風の流れは，循環規模による違いだけではなく地域による 違いもある。特にわが国における気候の地域差は, 国土が南北に 長いことや中央部に気候境界を形成する山脈があることなどから 複雑である。したがって, 本研究で対象とする青森, 秋田, 岩手, 山形，宮城，福島の東北 6 県のアメダス気象観測点について，気 候の地域差を考慮して検討を進めることとした。日本の気候区分 にはいくつかの方法がある ${ }^{8)}$ が, 本研究では大気候を構成する最 も重要な要素である気温と降水量に基づいて ${ }^{9)}$, 東北地方のアメ ダス気象観測点を日本海側と太平洋側とに区分した。

図 1 は，東北地方におけるアメダス気象観測点の地域区分を示 したものである。東北地方日本海側の観測点は 72 個所, 東北地方 太平洋側の観測点は 73 個所に区分された。ただし, 福島県太平洋 側は，年間降水量が北東北地方太平洋側と比べると多く，関東圈 の区分に属するので, 本研究では福島県太平洋側を除いた青森県, 岩手県, 宮城県の 57 個所を東北地方太平洋側の観測点とした。

なお，季節区分は気象学の分野で用いられている区分に従い， 春季は $3 \sim 5$ 月, 夏季は $6 \sim 8$ 月, 秋季は $9 \sim 11$ 月, 冬季は 12 〜2月とした。

\section{3. 風の流れを表す指標の定義}

風は風向と風速の $2 つ の$ 量によって示されるべクトル量である。

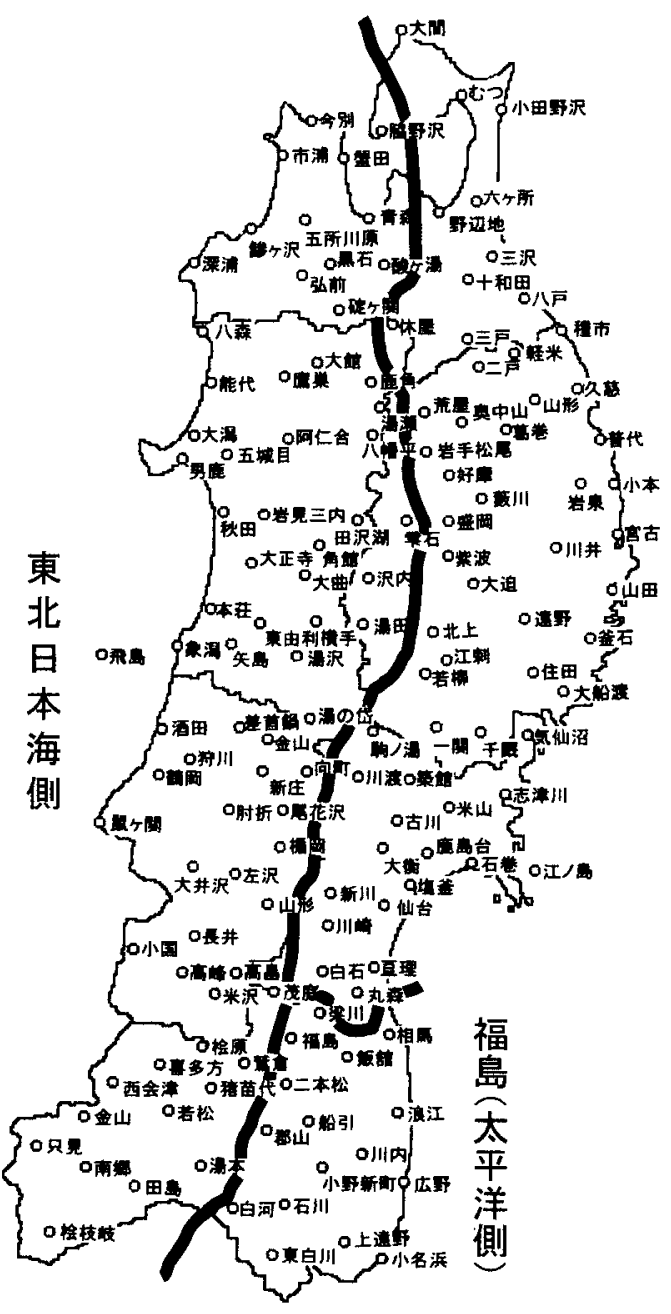

図 1 アメダス気象観測点の区分
したがって，風の流れが環境に及ぼす影響について考える場合に は, どれぐらいの強さの風がどの方向から吹くかについて知る必 要がある。そこで本研究では, 以下の項目を風の流れを表す指標 として定義した。なお, 風向, 風速については, 1 日 24 回, 毎正 時に観測されたデータを用いることとし，気象庁監修アメダス観 測年報 CD-ROM 版の 1987 年から 1996 年までの過去 10 年間の観 測值を用いた。

また，いずれの定義においても，季節のようなある期間を対象 として, 10 年間の観測データについて集計を行った。

(a) 風向頻度 $F_{\mathrm{i}}(\%)$ : 全観測回数に対する 16 方位別の観測回数 を百分率で示したもので，式(1)によって表される。

$F_{\mathrm{i}}=N_{\mathrm{i}} / N A \times 100 \quad(\mathrm{i}=\mathrm{N}, \mathrm{NNE}, \cdots, \mathrm{NW}, \mathrm{NNW})$

（b）平均風速 $V_{\mathrm{i}}(\mathrm{m} / \mathrm{s})$ : 全観測データの風速を 16 方位別に集計 して平均值を求めたもので, 式 (2)によって表される。

$V_{\mathrm{i}}=\Sigma v_{\mathrm{i}} / N_{\mathrm{i}} \quad(\mathrm{i}=\mathrm{N}, \mathrm{NNE}, \cdots, \mathrm{NW}, \mathrm{NNW}) \cdots \cdots \cdots$

ここで, $N A:$ 全観測回数

$$
\begin{aligned}
& N_{\mathrm{i}}: 16 \text { 方位別の観測回数 } \\
& v_{\mathrm{i}}: 16 \text { 方位別に観測された風速 }(\mathrm{m} / \mathrm{s})
\end{aligned}
$$

\section{4. 因子の定義}

微気象に影響を与えるのは数 $\mathrm{km}$ 範囲内の地形であることから， 本研究では観測点を中心に半径 $1 \mathrm{~km}$ 以内の範囲を対象として, 風 向, 風速に影響を与えると考えられる地形の状態と樹木による減 風効果を定量的に表す因子を定義した。表 1 に各因子の定義を示 す。

$4 \cdot 1$ 地形因子

地形因子として 10 種類を取り上げた。このうち, 標高範囲と障 害距離については観測点との標高差が $100 \mathrm{~m}$ の場合と, $200 \mathrm{~m}$ の場 合をそれぞれ因子として定義したので, 地形因子の数は 10 種類 12 因子である。これらの地形因子を採用した理由は, 次のとおり である。

(1)海岸距離は, 海岸までの最短距離を表している。障害物のな い海上では陸上に比べ強い風が吹く。また, 海上と陸上では温度 差があるため沿岸で観測される風は, 海陸風に代表されるように 内陸部で観測される風と異なる傾向を示す 10) といわれている。し たがって，この因子を用いることによって，海の有無だけではな く, 海までの距離が風に与える影響についても考慮することがで きる。

\begin{tabular}{|c|c|c|c|c|c|}
\hline & \multicolumn{2}{|c|}{ 因子名 } & 嘌号 & 単位 & 定 \\
\hline & \multicolumn{2}{|l|}{ (1)海岸距襍 } & $S$ & (m) & 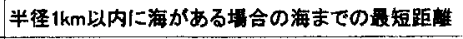 \\
\hline & \multicolumn{2}{|l|}{ (2)海技高度 } & $L$ & (m) & 詪測点の海面からの高さ \\
\hline & \multicolumn{2}{|c|}{ (3)最高点掼高蕫 } & $M a$ & $(m)$ & 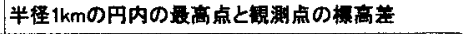 \\
\hline & \multicolumn{2}{|c|}{ (4)最低点䍘高荎 } & $M i$ & $(\mathrm{~m})$ & 半径1kmの円内の最低点と钼测点の标滈差 \\
\hline & \multicolumn{2}{|c|}{ (5)橉高の価美 } & $L d$ & $(\mathrm{~m})$ & 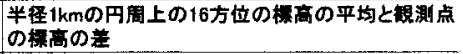 \\
\hline 地 & \multicolumn{2}{|c|}{ (6)地形傾斜の售美 } & $K$ & & 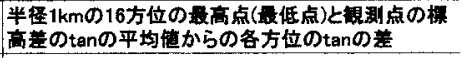 \\
\hline \multirow{2}{*}{$\begin{array}{l}\text { 形 } \\
\text { 因 }\end{array}$} & \multirow{2}{*}{ (7)棈高筙目 } & 100 & Ro & $(\%)$ & 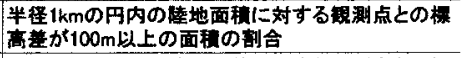 \\
\hline & & 200 & Rt & $(\%)$ & 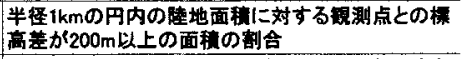 \\
\hline \multirow[t]{4}{*}{ 子 } & \multicolumn{2}{|l|}{ (8)開放度 } & $A$ & $0^{\circ}$ & 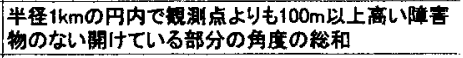 \\
\hline & \multicolumn{2}{|l|}{ (9)流通方向 } & $D$ & $0^{\circ}$ & 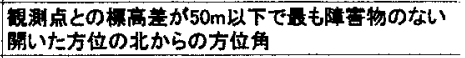 \\
\hline & \multirow{2}{*}{ (10)障害距㫿 } & 100 & Ho & (m) & 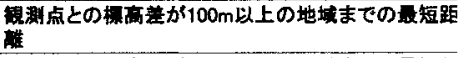 \\
\hline & & 200 & $H t$ & (m) & 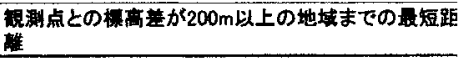 \\
\hline 澍社 & \multicolumn{2}{|l|}{ (11)墄風车 } & $G$ & (\%) & 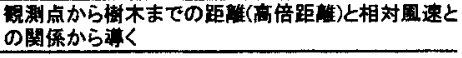 \\
\hline
\end{tabular}

表 1 因子の定義 
(2)海抜高度は，観測点の海面からの高さを表している。一般に 海抜高度が高くなると風速は増加寸るといわれている ${ }^{11)}$ ので, 海 抜高度を因子とすることで標高と風速との関係について考慮する ことができる。

(3)，(4)の最高点および最低点標高差は，周辺の地形を代表する 点として最高点および最低点を取り，観測点との標高差を因子と したものである。風は周辺の標高が高ければ遮られるが，低けれ ばその方向へ向かって流れていく。したがって，この因子を用い ることによって，観測点との相対的な高さの違いによる風の吹き やすさを考慮することができる。

(5)標高の偏差は，半径 $1 \mathrm{~km}$ の円周上で 16 方位の標高值の平均 值と観測点の標高の差をとったものである。風はある方位または ある一点における地形の影響だけを受けているのではなく，周辺 の連続した地形の影響を受けて変化している。標高の偏差は他の 因子と異なり，周辺の連続した地形の状況を反映することができ る因子である。

(6)地形傾斜の偏差は, 16 方位線上で最高点または最低点の標高 值を用いて正接 $(\tan )$ を求め, 16 方位の $\tan$ の平均值と各方位の $\tan$ の差を因子としたものである。標高の偏差と同様に周辺の連続し た地形の影響を反映する因子であるが，標高の偏差よりもさらに 詳細に周辺の地形を反映することができる。最高点または最低点 の標高とその地点までの距離について考慮していることと，1 の観測点について各方位で值が算出される，すなわち，16 個の值 が得られることがその理由である。

(7)風を遮るもののない平野などの開けたところでは, 山岳や建物 の密集している市街地よりも風は強くなることが知られている ${ }^{12)}$ そこで, 風を遮る障害物の存在を因子としたものが, 標高範囲 100 および 200, 開放度, 流通方向, 障害距離 100 および 200 の 4 種 類 6 因子である。

これらの因子のうち, 障害物の占める面積の割合を表したのが, 標高範囲 100 および 200 である。この因子によって，障害物が風 に及ぼす影響を，面積比をパラメータとして考慮することができ る。

(8)開放度は，障害物のない開けている部分の角度の総和を表し ている。この因子を用いることによって，地形の開け具合と風の 吹きやすさの関係について考虑することができる。

(9)流通方向は，障害物が最も少ない方向の北からの方位角を示 している。この因子を用いることによって，最も風の吹き込みや すい方位について考慮することができる。

(10障害距離 100 および 200 は，障害物までの最短距離を表して いる。障害物が近くにあるほど風は大きな影響を受けるので，こ の因子を用いることによって，障害物が風に及ぼす影響について 距離をパラメータとして考慮することができる。

\section{$4 \cdot 2$ 樹木因子}

風には地形以外の要因も大きく影響していると考えられる。そ の要因として，観測点周辺の樹木，建物などによる影響が考えら れる。なかでも樹木には防風林に代表されるように大きな減風効 果があることが知られている。減風効果とは，樹木が風に対する 障害物となり，風の持つエネルギーを奪うことによって風が弱ま る作用のことである ${ }^{13)}$ 。また，開発による地形改変が行われる山 地は，樹木で覆われている場合がほとんどであり，山地の切り取 りに伴って樹木の伐採が行われる場合が多い。したがって，本研 究では地形以外で特に風に影響を与える要因として, 樹木を取り 上げ，樹木の風に対する影響を考慮するため，減風率を樹木因子 として加えることとした。

図 2 は，樹木の高さを $H_{0}$ とし，式 (3) に示す樹木からの距離を
$H_{0}$ の倍数で表した高倍距離と，風上側一 10 で観測された風速を $100 \%$ とした相対風速との関係を示したものである ${ }^{13)}$ 。この減風 曲線から，相対風速を高倍距離の関数 $\mathrm{f}(H)$ とした。そして, 100 $\%$ から相対風速を減じた值を減風率として, 式 (4) のように定義 した。

$$
H=l / H_{0}
$$

$G=100-\mathrm{f}(H)$

ここで, $H:$ 高倍距離

$$
\begin{aligned}
& l: \text { 樹木からの距離 }(\mathrm{m}) \\
& H_{0}: \text { 樹木の高さ }(\mathrm{m}) \\
& G: \text { 減風率 }(\%)
\end{aligned}
$$

本研究では, 16 方位線上でそれぞれ減風率を算出した。

図 2 をみると，樹木の葉が落葉した場合の相対風速の方が，繁 茂した状態より高い值を示しており, 減風率は夏季に比べて冬季 に低下寸ることがわかる。

なお，地形因子は，国土地理院発行 CD-ROM 版の数值地図 50 m メッシュ (標高) をもとにして求めた。また, 樹木因子につい ては, 国土地理院発行 CD-ROM 版の数值地図 25,000( 地図画像) をもとに, 観測点周辺の樹種および観測点から樹木までの距離を 調べ, 樹高を針葉樹 $15 \mathrm{~m}$, 落葉樹 $10 \mathrm{~m}$, 果樹 $3 \mathrm{~m}$, 竹 $9 \mathrm{~m}$, 桑 $2 \mathrm{~m}$ として減風率を算出した。

\section{5. 地形因子による地形形態の分類}

アメダス気象観測点は, 設置個所周辺の地形が考慮されていな い場合がほとんどである。そのためアメダス気象観測データは, 隣り合った観測点でも異なる傾向を示すことがあり, 周辺の地形 の影響を受けていると考えられる。そこで, 各観測点における風 速別の風向頻度を求め，地形の状態による風の傾向を調べた。

図 3(a) は鹿島台観測点における風速別の風向頻度で, 図 3(b) は 観測点周辺の地形図を示したものである。図から, $4.0 \mathrm{~m} / \mathrm{s}$ 未満の 低風速での風配図は卓越風向が認められないが, $4.0 \mathrm{~m} / \mathrm{s}$ 以上の風 速の場合には卓越する風向が定まっていることがわかる。これは, 地形の影響を受けていない風の一般的な傾向である。

一方, 図 4(a) と (b) に示した小本観測点の場合は, $4.0 \mathrm{~m} / \mathrm{s}$ 未満 と $4.0 \mathrm{~m} / \mathrm{s}$ 以上の風配図は類似し, さらにその卓越風向方位は西 から西南西となっている。これは，地形の開けている方位，すな わち風が吹き込むと考えられる方位と一致しており，地形の影響 を受けていることがわかる。

その他のアメダス気象観測点においても, 観測される風は周辺 の地形の状態によって異なる傾向を示すことが確認された。した がって, 地形を形態別に分類することによって, 風の流れの傾向 を分類することが可能になると考えられる。そこで，アメダス気 象観測点を表 1 に示した地形因子を用いて, 微気象に影響を与え ると一般的に考えられている沿岸，平地，平地と山の混在，山間 の 4 つの地形形態 ${ }^{14)}$ に次の順序で分類した。

（1） 観測点から半径 $1 \mathrm{~km} の$ 範囲内に海がある観測点 $(0<S \leqq$

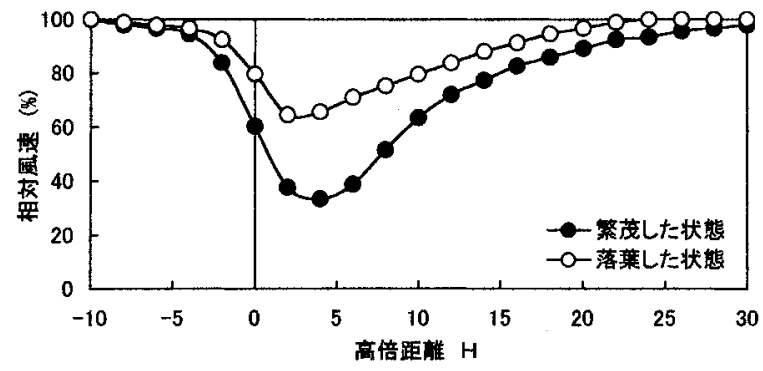

図 2 高倍距離と相対風速との関係 


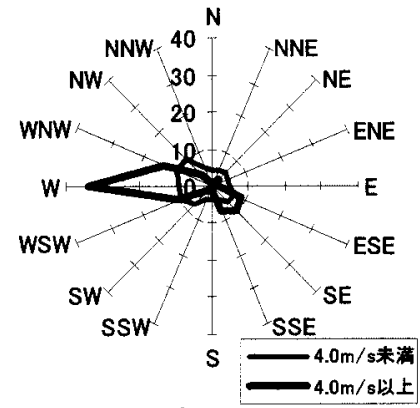

(a) 風速別風配図

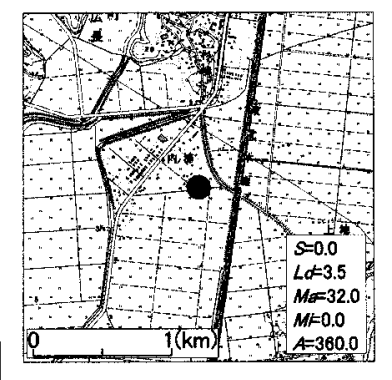

(b) 钼測点周辺地図
図 3 鹿島台観測点

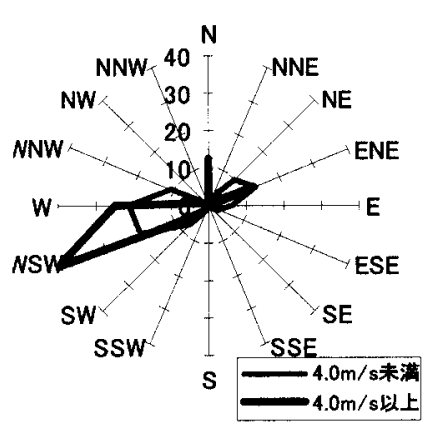

(a) 風速別風配图

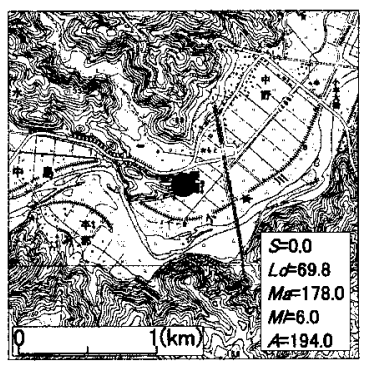

(b) 钼測点周辺地図
図 4 小本観測点

1000)は「沿岸」とする。

(2) 最高点標高差および最低点標高差がそれぞれ $50 \mathrm{~m}$ 以下 $(M a, M i \leqq 50)$ で, 標高の偏差が $\pm 20 \mathrm{~m}$ 以下 $(-20 \leqq L d \leqq 20)$ の観 測点は「平地」とする。

(3) 最高点標高差が $50 \mathrm{~m}$ より大きく $(M a>50)$, さらに開放度 が $270^{\circ}$ 以上 $(A \geqq 270)$ の観測点は「平地と山の混在」とする。

(4) 開放度が $270^{\circ}$ 未満 $(A<270)$ の観測点は「山間」とする。

この分類方法を用いることによって, 周辺の地形情報があれば, どのような傾向の風が吹く地点であるのかを推定することが可能 となる。

表 2 に, 地形因子を用いた地形形態の分類条件と分類結果を示 す。分類は東北地方のアメダス気象観測点 129 個所について行っ た。なお, 東北地方太平洋側の 5 個所の観測点は, 山頂や山腹な どにあるために，4つの地形形態のいずれにも属さなかった。

\section{6. 重回帰分析による予測式の導出}

風が地形的にどの方向から最も吹きやすいのか, どのくらいの 速さで吹くのかを予測するために，風の流れと影響因子との関係 について，重回帰分析を行った。

重回帰分析とは，目的変数とそれに影響すると考えられる説明 变数との間の関係式を求め, 説明変数の值から目的変数の值を予 測したり，説明変数の影響の大きさを評価したりすることができ る統計的解析手法の 1 つである ${ }^{15)}$ 。したがって, この手法を用い て風の流れと各因子間との関係式を導くことができれば，因子の 值から風の流れを予測することが可能となる。そこで, 風向頻度, 平均風速を目的変数, 地形および樹木因子を説明変数として重回 帰分析を行った。

重回帰分析の解析方法は，はじめに予備的解析を行い，因子相 互の単相関係数が 0.8 以上を示寸類似因子については，目的変数 との相関の低い因子を省き，残りの因子を用いて重回帰分析を 行った。次に，導かれた関係式を信頼性の高い予測式として用い
表 2 地形因子による地形形態の分類条件および分類結果

\begin{tabular}{|c|c|c|c|}
\hline \multirow{2}{*}{ 地形形悡 } & \multirow{2}{*}{ 分類策件 } & \multicolumn{2}{|c|}{ 分類結果 } \\
\hline & & 日本海溉 & 太平洋側 \\
\hline 治岸 & $0<s \leqq 1000$ & 9 & 8 \\
\hline \multirow{3}{*}{ 平地 } & $M a \leqq 50$ & \multirow{3}{*}{22} & \multirow{3}{*}{13} \\
\hline & $M i \leqq 50$ & & \\
\hline & $-20 \leqq L d \leqq 20$ & & \\
\hline \multirow{2}{*}{ 平地と山の湿在 } & $M a>50$ & \multirow{2}{*}{24} & \multirow{2}{*}{20} \\
\hline & $A \geqq 270$ & & \\
\hline 山间 & $A<270$ & 17 & 11 \\
\hline その他 & - & 0 & 5 \\
\hline
\end{tabular}

るためには，重相関係数の高い関係式を得なければならない。そ のためには変数選択によって重要度の低い因子を省く必要があ る。そこで本研究では, 変数減増法を用いる対話型変数選択法 ${ }^{16)}$ によって変数選択を行い, 最も精度の良い因子の組み合わせを導 いた。変数減増法とは, 目的変数に対する影響度を表す係数であ る標準偏回帰係数をもとに，この值の小さい因子を順に除きなが ら，場合によっては一度除いた因子を再度選択しながら，重回帰 分析を繰り返す方法である。なお，解析は大気候による地域差を 考慮するために, 日本海側と太平洋側とに区分して行った。

\section{$6 \cdot 1$ 地形形態別の風向 - 風速と影響因子との関係}

5. で述べたとおり, 風の流れは観測点周辺の地形形態によって 異なる傾向を示す。したがって, 地形形態ごとに風の流れと影響 因子との関係について解析を行う必要があるといえる。また，わ が国においては, 夏季は南東, 冬季は北西というように季節によっ て卓越する風向が異なる傾向を示す ${ }^{17)}$ ので, 季節別に解析を行う 必要がある。そこで, 東北地方日本海側と太平洋側のアメダス気 象観測点を, 4 つの地形形態に分類して, 形態ごとに季節別の風 向頻度および平均風速を求めて, 前述の解析手順に従って重回帰 分析を行った。

なお東北地方における樹木の葉の状態を考慮して，6 月から 11 月の夏季と秋季を樹木の葉が繁茂した状態，12 月から 5 月の冬季 と春季を樹木の葉が落葉した状態として減風率の算出を行った。 また，日本海側および太平洋側のいずれの気候区分においても， 地形形態が沿岸の観測点については, 観測点数が少ないために解 析を行うことができなかった。さらに，太平洋側の山間の地形形 態の観測点も，同様の理由で解析を行うことができなかった。

表 3 は, 風向頻度に関する地形形態および季節別の解析結果を 示したものである。表中の偏回帰係数とは, 関係式において各変 数項の係数となる。標準偏回帰係数とは, 単位が異なる説明変数 間の目的変数に対する影響度を比較するのに用いられる係数であ る。自由度修正済み重相関係数とは, 無意味な説明変数を用いた 場合には数值が下がるように自由度で補正した重相関係数のこと である。重相関係数とは, 重回帰分析の精度を表している。なお, 自由度修正済み重相関係数が 0 となり相関を求めることができな かった季節は，空欄となっている。

表 4 は, 平均風速に関する地形形態および季節別の解析結果を 示したものである。

これらの表から，いずれの気候区分および地形形態においても， 春季と秋季の多くの場合で, 相関係数が低いか相関を求めること ができない傾向にあることがわかる。これは, 春季の $3 \sim 4$ 月頃 に冬の季節風が，また秋季の $9 \sim 10$ 月に夏の季節風が収まり，そ れぞれ夏および冬の季節風に切り替わる時期 18) であるため, 風向 が定まらず影響因子との間に明瞭な関係を得ることができないた めと考えられる。したがって, 春季と秋季における関係式を予測 式とするのは，信頼性に欠けると判断される。 
表 3 風向頻度の重回帰分析結果

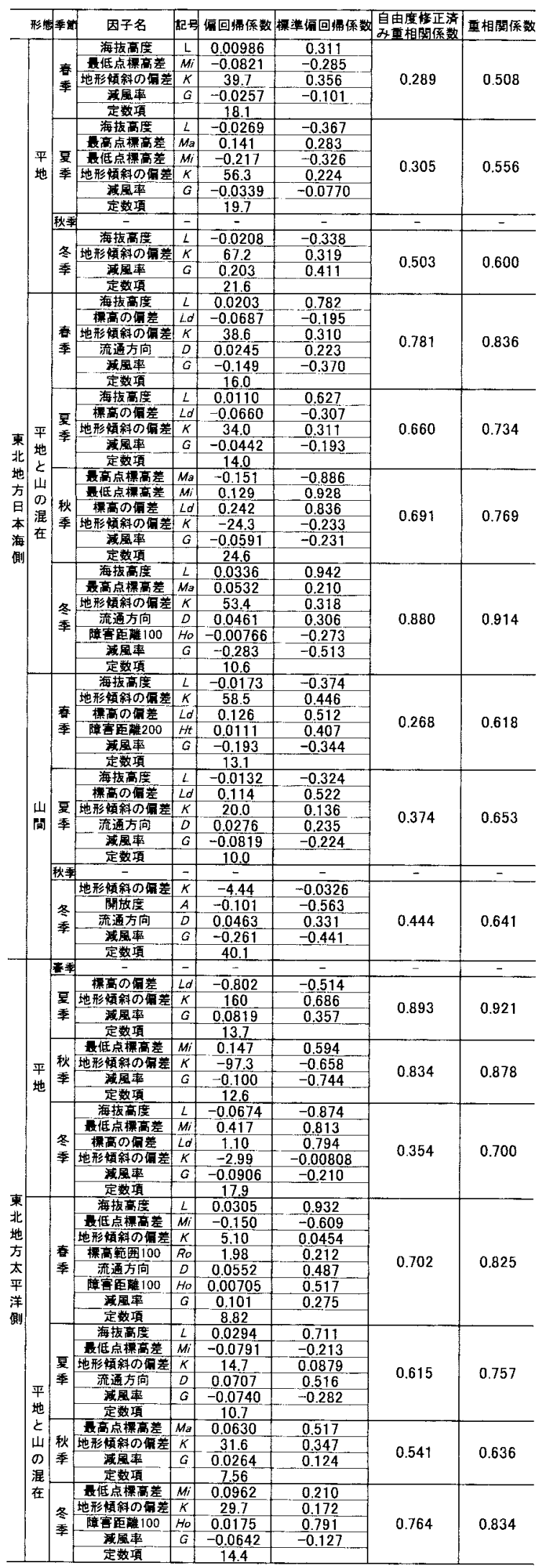

表 4 平均風速の重回帰分析結果

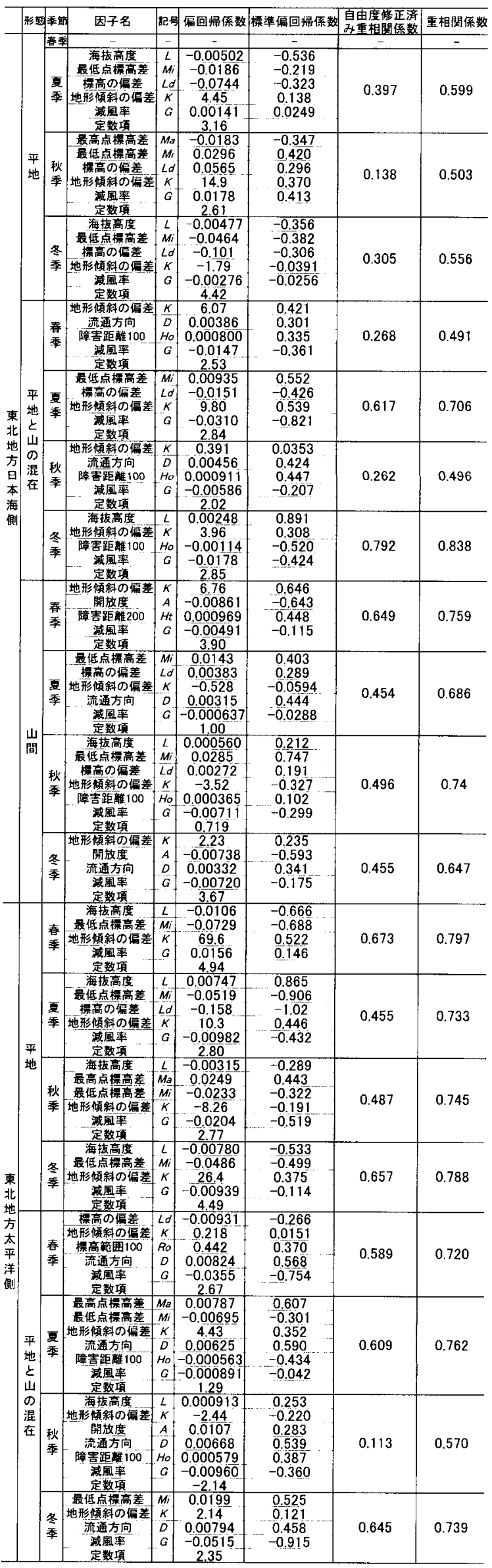


さらに表から, 平地と山の混在する地形形態についてみると, 両気候区分ともに自由度修正済み重相関係数は，夏季と冬季では 0.6 以上の值を示していることがわかる。このことから, 平地と山 の混在する地形形態における風向および風速は, 周辺の地形や樹 木との関係が，他の地形形態に比べてより強く現れているものと 考えられる。また，山地が国土の $80 \%$ 以上を占めるわが国では, 平地から山地一移り変わるような, 平地と山の混在する地域が 様々な開発行為の対象となる場合が多い。したがって，このよう な地域において開発に伴う地形改変が周辺の風体系にどのような 影響を与えるかを予測することは重要なことであるといえる。

以上のことから, 平地と山の混在する地形形態における東北地 方日本海側および太平洋側の風向頻度 $F(\%)$ の関係式として式 (5) 〜 (8) が求められた。

・東北地方日本海側

夏季 $F_{j s u i}=0.0110 L-0.0660 L d+34.0 K_{\mathrm{i}}-0.0442 G_{\mathrm{i}}+14.0$

冬季 $F_{j w \mathrm{i}}=0.0336 L+0.0532 \mathrm{Ma}+53.4 K_{\mathrm{i}}+0.0461 D$ $-0.00766 H o-0.283 G_{\mathrm{i}}+10.6$

・東北地方太平洋側

$$
\begin{aligned}
& \text { 夏季 } F_{p s u i}=0.0294 L-0.0791 M i+14.7 K_{\mathrm{i}}+0.0707 D \\
& -0.0740 G_{\mathrm{i}}+10.7 \\
& \text { 冬季 } F_{p w i}=0.0962 M i+29.7 K_{\mathrm{i}}+0.0175 H o-0.0642 G_{\mathrm{i}}+14.4
\end{aligned}
$$

同じく東北地方日本海側および太平洋側の平均風速 $V(\mathrm{~m} / \mathrm{s})$ の関 係式として式 (9)〜 (12) が求められた。

·東北地方日本海側

夏季 $V_{j s u \mathrm{i}}=0.00935 \mathrm{Mi}-0.0151 L d+9.80 K_{\mathrm{i}}-0.0310 G_{\mathrm{i}}+2.84$ ….......... (9)

冬季 $V_{j w \mathrm{i}}=0.00248 L+3.96 K_{\mathrm{i}}-0.00114 H o-0.0178 G_{\mathrm{i}}+2.85$

- 東北地方太平洋側

夏季 $V_{p s u \mathrm{i}}=0.00787 \mathrm{Ma}-0.00695 \mathrm{Mi}+4.43 K_{\mathrm{i}}+0.00625 \mathrm{D}$ $-0.000563 \mathrm{Ho}-0.000891 G_{\mathrm{i}}+1.29 \cdots \cdots \cdots \cdots \quad$ (11)

冬季 $V_{p w i}=0.0199 M i+2.14 K_{\mathrm{i}}+0.00794 D-0.0515 G_{\mathrm{i}}+2.35$ …............ (12)

$(i=N, N N E, N E, \cdots, N W, N N W)$

ここで, $L:$ 海抜高度 $(\mathrm{m})$

$$
\begin{aligned}
& M a: \text { 最高点標高差 }(\mathrm{m}) \\
& M i: \text { 最低点標高差 }(\mathrm{m}) \\
& L d: \text { 標高の偏差 }(\mathrm{m}) \\
& K: \text { 地形傾斜の偏差 } \\
& D: \text { 流通方向 }\left({ }^{\circ}\right) \\
& H o: \text { 障害距離 } 100(\mathrm{~m}) \\
& G: \text { 減風率 }(\%)
\end{aligned}
$$

これらの関係式の重相関係数は，いずれも 0.7 以上の高い值を 示しており, これらを地形改变を伴う開発地域周辺の風向, 風速 変化を予測する式として用いるのに十分な精度を有するものと判 断される。

\section{7. 地形改変を伴う開発地域周辺の風向・風速変化予測}

6. で導かれた予測式を用いて, 地形改変を伴う開発計画を事例 として, 開発の前後で周辺地域の風向, 風速がどのように変化す るのか予測を行った。

研究事例としては, 山形県内にある標高 $194 \mathrm{~m}$ の山を対象とし, この山を切り取って得られる岩石は砕石用原石として利用し, 跡 地に運動公園を建設する複合開発計画を想定して予測を行った。
標高 $130 \mathrm{~m}$ レベルまで山の切り取りを行った場合, 約 33 ha の用 地が造成され, 野球場や陸上競技用トラックなどの施設を建設す るのに十分な用地が得られる。したがって, 現状の地形を開発前 とし, 標高 $130 \mathrm{~m}$ レベルまで山地を切り取った地形を開発後とし て, 開発前および開発後における風の流れについて予測を行った。 なお開発対象地域は，住宅地および田畑がある平地に対象とする 山があり, 平地と山の混在する地形形態である。また, 開発対象 の山は樹木に覆われており, 山地の切り取りが行われる区域の樹 木は，開発に伴って伐採されるものとした。

開発地域周辺の風体系変化を予測するために, 開発計画地を中 心として, 東西南北に $200 \mathrm{~m}$ 間隔で $11 \times 11$ のメッシュを切り,メッ シュの交点 121 点について予測を行った。各交点において, それ ぞれ半径 $1 \mathrm{~km}$ の範囲の地形と樹木の分布状況をもとに各因子の算 出を行った。なお，対象とする開発地域が東北地方日本海側にあ ることから東北地方日本海側における予測式を用いた。また，東 北地方では冬季の季節風による風害がしばしば発生することなど から，ここでは冬季の予測結果について述べる。なお，東北地方 日本海側の平地と山の混在する地形形態における冬季の風向頻度 および平均風速の予測式の重相関係数は, 0.914 および 0.838 であ り，予測式としての精度は十分なものであると判断される。

図 5 は, 開発前および開発後における卓越風向とその方位の風 向頻度の予測結果を示したものである。卓越風向方位は, 式 (5)に よって計算される 16 方位の風向頻度のうちで, その值が最大とな る方位として定めた。図中の矢印の向きが卓越風向方位を示し, その長さが風向頻度を表している。太い矢印は, 開発後に卓越風 向方位が変化すると予測された地点の開発後の卓越風向とその方 位の風向頻度を表している。なお, 図中の灰色で示した部分が, 開発計画地を表している。図から, 卓越風向は山頂を中心として 放射状になることがわかる。これは，今回対象とした開発事例で は, 開発対象の山が平地部に独立峰として存在するため, 周辺の 地形の状態から最も風の吹きやすい方位が，山頂からの吹き下ろ しの方向になるものと考えられる。卓越風向頻度は, 開発前には 山の中腹で $15 \sim 35 \%$, 平地部で $10 \sim 35 \%$ の值を示し, 開発後 には中腹では $10 \sim 20 \%$, 平地部では $10 \sim 30 \%$ の值を示す。な お, 開発後に $20 \%$ 前後の值の地点がほとんどであることから, 開 発前に比べると周辺地域の卓越風向頻度に差がみられなくなるこ とがわかる。また, 開発前に比べて卓越風向方位が変化すると予 測された地点は 43 個所である。卓越風向方位が開発後に最も変化 するのは開発計画地の西北西端の地点で, 卓越風向方位が東から 西南西へと方位角で $157.5^{\circ}\left(=22.5^{\circ} \times 7\right)$ も変化すると予測された。

図 6 は, 卓越風向頻度の変化を比で表したものである。図中の 数值は, 開発前に対する開発後の卓越風向頻度の比で, 1.00 以上 の地点は開発後に卓越風向頻度が増加する地点を, 1.00 以下の地 点は開発後に卓越風向頻度が減少する地点を示している。なお下 線を引いた数值は, 開発後に卓越風向方位が変化すると予測され た地点を表しており, 開発後の卓越風向方位における開発前後の 風向頻度の変化比を示している。

図から, 開発計画地内では開発後に卓越風向頻度が増加するの に対して, 周辺の平地部では開発後に減少することがわかる。ま た, 最も変化比の大きい地点は開発計画地内の北西端で, 開発前 $6.9 \%$ であった風向頻度が開発後には $19.0 \%$ 一と 2.75 倍になると 予測された。

次に, 風速の変化予測を行った。図 7 は, 開発前および開発後 における卓越風向方位における平均風速の予測結果を示したもの である。卓越風向方位は, 図 5 に示寸予測結果の方位とした。図 中の矢印の向きが卓越風向方位を示し, その長さが平均風速を表 


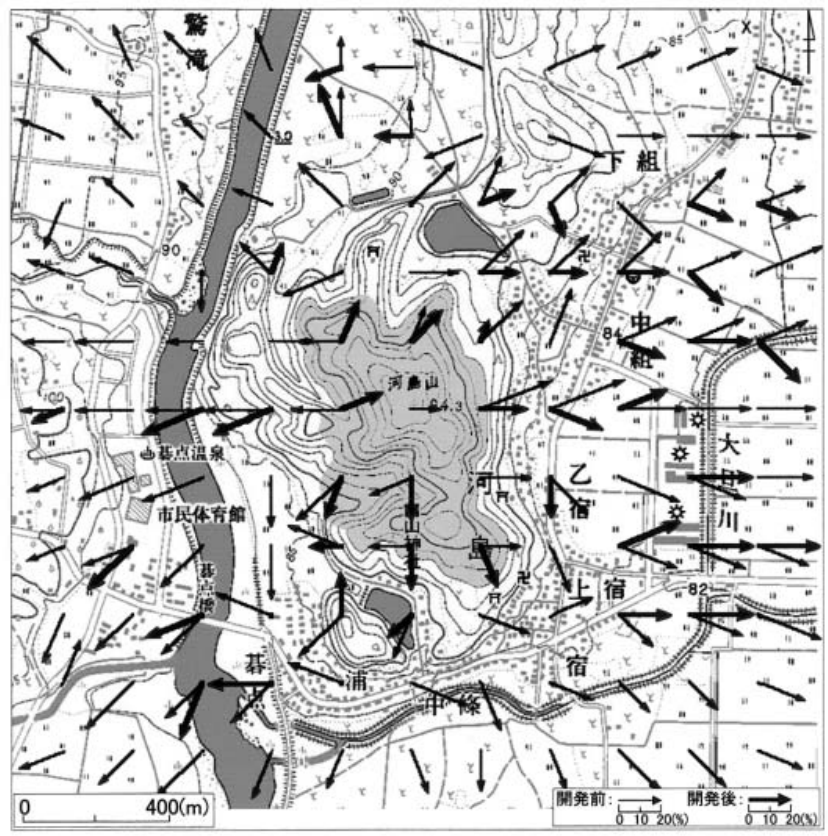

図 5 開発前後の卓越風向とその方位の風向頻度

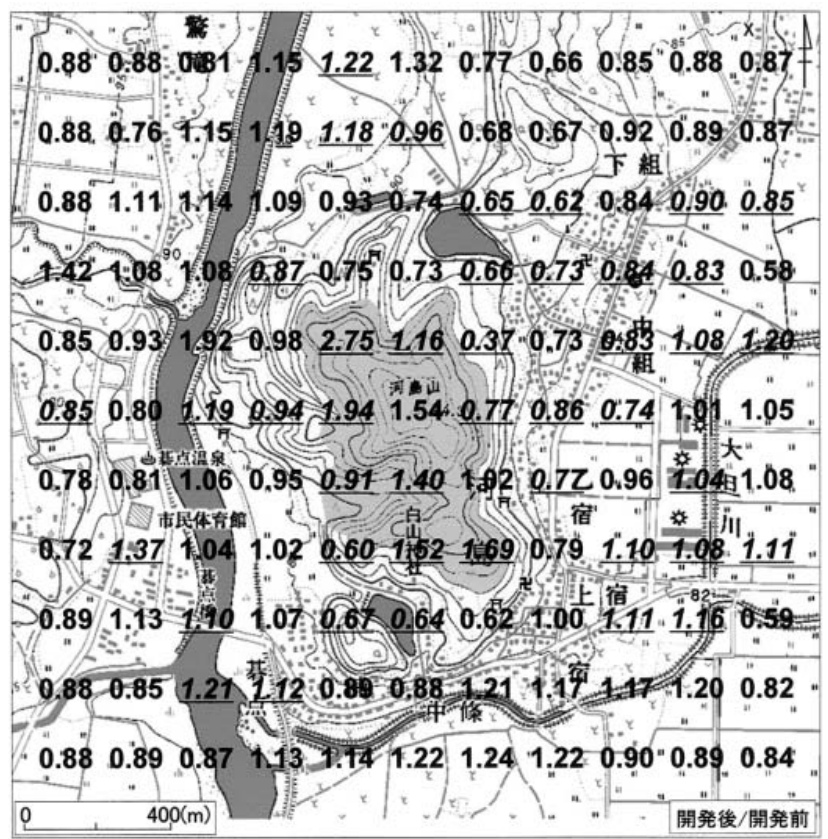

図 6 開発前後の卓越風向頻度の変化比

している。図から，開発計画地内における平均風速は $3.0 \sim 4.0 \mathrm{~m}$ $/ \mathrm{s}$ で，開発計画地の端から $400 \mathrm{~m}$ ほど離れた範囲における平均風 速は $2.5 \sim 3.0 \mathrm{~m} / \mathrm{s}$ とやや遅くなり, 開発計画地から $1 \mathrm{~km}$ 程度離 れた地域では $3.0 〜 3.5 \mathrm{~m} / \mathrm{s}$ になると予測された。

図 8 は, 卓越風向方位における平均風速の変化を比で表したも のである。図から, ほとんどの地点において, 平均風速の変化比 が 1.00 以上であることから, 山地の切り取りが行われる開発後に は，周辺地域の平均風速が速くなることがわかる。最も変化比の 大きい地点は開発計画地の北西側で, 開発前 $2.3 \mathrm{~m} / \mathrm{s}$ であった平均 風速が開発後には $4.0 \mathrm{~m} / \mathrm{s}$ へと変化し, 1.57 倍になると予測された。

以上の予測結果から，開発に伴って山地の切り取りを行うこと によって, 周辺地域の風向および風速に変化が生じることが明ら かとなった。また，開発計画地内およびその付近では，開発後に

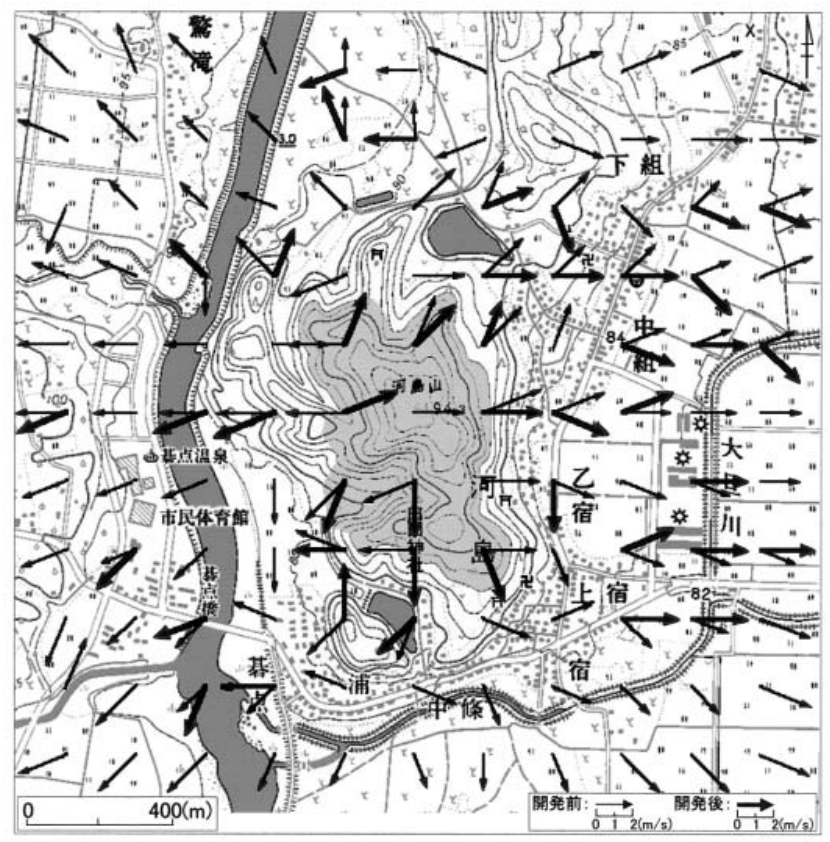

図 7 開発前後の卓越風向方位における平均風速

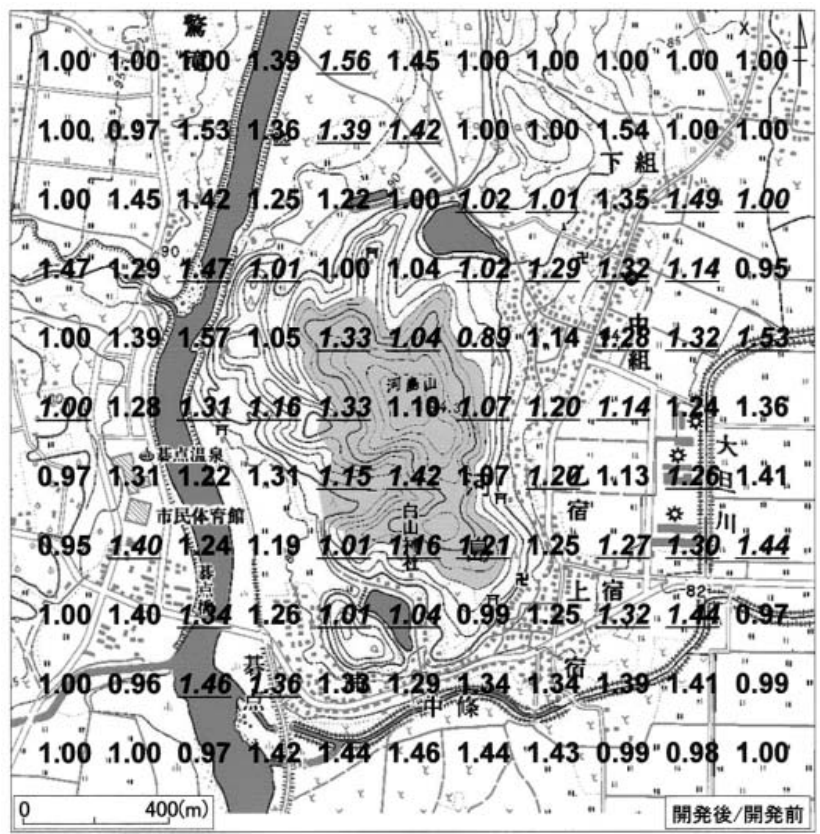

図 8 開発前後の卓越風向方位の平均風速の変化比

卓越風向方位が変化し，その方位における風向頻度と平均風速が それぞれ低下する傾向があると予測された。特に開発計画地内の 北西側では，山の切り取り高さが大きいために，風向および風速 が大きく変化すると予測された。さらに開発計画地の周辺では, 卓越風向頻度が低下して平均風速が速くなる傾向があると予測さ れた。これは, 開発に伴って開発計画地の標高が低くなることに よって, 周辺の地点では, 風の流れを遮る障害物の影響が小さく なり，風向頻度はある方向に極端に卓越しなくなり，風の流れが 速くなるためと考えられる。

$$
\text { 8. まとめ }
$$

本研究では, 地形改変を伴う開発地域周辺の風の流れの変化を 予測するに当たり，風の流れに影響を及ぼす地形の状態や樹木の 
分布をもとに地形因子および樹木因子を定義し，これらの因子と 風の流れとの関係について統計的検討を行った。得られた結果を まとめると，次のとおりである。

（1）風の流れは周辺の地形の状態によって異なる傾向を示す ことから，風を傾向別に分類する方法として，地形形態の分類を 行った。その結果，地形因子を用いて沿岸，平地，平地と山の混 在および山間の 4 つの地形形態に分類する方法を定めることがで きた。

（2）風の流れと地形および樹木因子との関係について重回帰 分析を用いて統計的検討を行った。その結果，平地と山の混在す る地形形態において, 東北地方日本海側と太平洋側における風向 頻度と平均風速の夏季と冬季の予測式を導くことができた。

（3）導かれた予測式を用いて開発地域周辺の風向，風速の変化 予測を行った。その結果，開発計画地内のほとんどの地点では卓 越風向方位が変化し，その方位における風向頻度および平均風速 がともに増加すると予測された。また，開発計画地の周辺の平地 部では，卓越風向頻度は開発後に減少する傾向があり，平均風速 は速くなる傾向があると予測された。

\section{引用 文 献}

1）大塚尚宽・関本善則 : 資源と素材, Vol. 109, No. 3, p. 203-208, (1993)

2）大塚尚寛・関本善則・齊藤 貢・鎌田 武: 資源と素材，Vol. 113, No. 7, p. 543 -548, (1997)

3）大塚尚寛 - 関本善則 - 齊藤 貢 -千葉 新 : 資源と素材, Vol. 113, No. 2, p. 115 $-120,(1997)$

4）横山長之：大気環境シミュレーション，白带書房 (東京), (1992)

5）只木良也：森林環境科学，朝倉書店 (東京), p. 86-88, (1996)

6) 荒木眞之 : 森林気象, 川島書店 (東京), p. 92-94, (1995)

7) 青木 滋 - 大草重康・奥田 穣・根 勇・永田 豊: 土木工学大系 2 , 彰国社 (東京), p. 88-96, (1977)

8) 吉野正敏 : 気候学, 大明堂 (東京), p. 36-43, (1978)

9) 前出 7), p. 67-97

10）吉野正敏：小気候，地人書館 (東京 ), p. 105-113,(1986)

11) 前出 9), p. $158-160$

12）伊藤 学: 風のはなしI，技報堂出版 (東京), p. 21-25, (1986)

3）真木太一：風害と防風施設，文永堂出版 (東京), p. 99-118, (1987)

14）真木太一：風と自然，開発社 (東京), p. 33-193, (1989)

15) 柳井晴夫・高木廣文: 多変量解析ハンドブック, 現代数学社 (京都), p. 18-30, (1989)

16）内田 治：寸ぐわかる EXCEL による多変量解析，東京図書 (東京)，p. 84-91, (1996)

17）倉嶋 厚：日本の気候, 古今書院 (東京), p. 169-179, (1966)

8）前出 17), p. 169-179 